\title{
E-Learning 3.0 = E-Learning 2.0 + Web 3.0?
}

\author{
Dr. Fehmida Hussain \\ Senior Lecturer School of Science and Technology, Middlesex University Dubai
}

\begin{abstract}
Web 3.0, termed as the semantic web or the web of data is the transformed version of Web 2.0 with technologies and functionalities such as intelligent collaborative filtering, cloud computing, big data, linked data, openness, interoperability and smart mobility. If web 2.0 is about social networking and mass collaboration between creator and user, then the Web 3.0 is referring to intelligent applications using natural language processing, machine-based learning and reasoning. From the perspective of advancement in eLearning, the web 2.0 technologies have transformed the classroom and converted a passive learner into an active participant in the learning process. This paper posits that the way both previous generations of eLearning (1.0 and 2.0) have emerged with the prevalent technologies in their kin Web versions (1.0 and 2.0, respectively), it can be argued that e-Learning 3.0 will provide all earlier generations' capabilities enhanced with the web 3.0 technologies. Furthermore in this paper, reviewing all the theories of learning and examining closely the theory of connectivism (considered to be the theory of learning for the digital age), it is argued that since most of the technologies that are to be a part of e-Learning 3.0 are addressed by these principles, a call for a new learning theory for e-Learning 3.0 is maybe not justified. Finally, a review of the secondary literature shows that there will be various challenges and issues related to prevalence and adoption of e-Learning 3.0 technologies, for example increased privacy and security risks, web accessibility, readiness of the users, be is the learner or the tutor, requirement for further standardization of e-Learning technologies issues, social issues in term of increase of the digital divide.
\end{abstract}

Keywords: e-Learning 2.0, e-Learning 3.0, Web 2.0, Web 3.0, Learning theories, semantic web, higher education, educational technology.

\section{Introduction}

E-Learning 3.0, is it the way ahead in educational technology or just another buzz word in the digitalspaces and education? At a prestigious IEEE conference, an interesting paper was published titled "E-Learning 2.0 = e-Learning 1.0 + Web 2.0" (Ebner, 2007, p. 1235)? After five years of incredible technological advancements, a reappraisal of the digital spaces is due; it is only fair to ask the question, Is E-Learning 3.0 = E-Learning 2.0 + Web 3.0? Thus, the topic and title of this paper. Exploring what entails e-Learning 3.0, there are three parts of this paper: (1) How Web 3.0 technologies will be incorporated in the existing e-Learning 2.0? (2) Is there a need for a new learning theory for e-Learning 3.0? (3) What are the challenges and issues related to adoption of e-Learning 3.0 ?

This paper first describes the three generations of Web, usually referred to as, the Web 1.0, Web 2.0 and the recently used neologism, Web 3.0. After explaining how the educational technologies and the information systems used in each are different, these are related to the concept of e-learning. E-Learning literature also broadly distinguishes between e-Learning 1.0, e-Learning 2.0 and e-Learning 3.0; hence the paper draws a parallel between the generations of the Web and e-Learning.

Next, in relation to e-Learning 3.0, as education researchers are questioning (Wheeler 2009b; Meichel, 2009) whether a new learning theory is required for e-Learning 3.0; so in the light of the existing learning theories, a preliminary attempt is made to address this. This paper does not indulge in the debate of whether connectionism is a theory or a phenomenon or for that matter does not counter the critique that has been done about it. The simple approach taken in this paper is to make the basis of the argument all important principles of the connectivist theory of learning and then examine how the technological shift maybe supported by these principles.

Nevertheless, with any advancement and more so, the technological advancement, there are associated challenges in terms of technological, ethical and social issues which are briefly discussed and highlighted in the end of the paper.

\section{How Web 3.0 technologies will be incorporated in the existing e-Learning 2.0?}

This section briefly covers the three generations of the web, then, describes how these technologies have been incorporated in e-Learning and finally illustrates how Web 3.0 technologies and functionalities give rise to e-Learning 3.0. 


\subsection{Evolution of the Web}

This section briefly covers the three generations of the Web in terms of the capabilities, technologies and usage. The web has evolved since the early days of the ENQUIRE project to the transformation of Web 3.0 (Berners-Lee et al., 2001; Berners-Lee 1995). Broadly speaking, web 1.0 connects real people to the world wide web (www), the web 2.0 connects real people who use the www and, the web 3.0 will connect the virtual representatives of the real people who use the www. So, where web 1.0 is about providing information, web 2.0 is about overload of information; web 3.0 is about control of information (Rego, 2011).

\subsubsection{Web 1.0 - the read Web (Web-as-information-source)}

Web 1.0 is generally referred to as the "read-only Web" (27 Rubens et al., 2011) making content available online for viewing. Authors of the web generally write what they want others to view and then publish it online. The reader can visit these web sites and can contact the writer or publisher if contact information is available. There is no direct link or communication between the two. Examples of these are static web sites and web pages created using HTML.

\subsubsection{Web 2.0 - the read/write web (Participatory Web)}

The term Web 2.0 is usually associated with the O'Reilly Media 2.0 conference (O'Reilly, 2004), but was actually used for the first time in early 1999 (DiNucci, 1999). As opposed to the Web 1.0 which is referred to as static web, Web 2.0 is considered as the dynamic web. The users can read, write and collaborate to a certain extent. The latest technologies used on client side or server side in Web 2.0 are Ajax (Asynchronous Javascript), XML (Extensible markup language), Adobe Flash, PHP, Per, Python, Flash and so on.

\subsubsection{Web 3.0 - the read/write/collaborate Web}

The technologies and concepts related to the neologism of Web 3.0, though still in the infancy stage are advancing quite rapidly. The Web 2.0 has given rise to silos of data being generated by social networking and otherwise, there will be a need to enable utilization of this data. An astounding statistics by the Forrester Research (2006) shows that $97 \%$ of the users never look beyond the top three search results when they are searching on the internet. So, all the data that has been selected is never really used. The main features of the Web 3.0 technologies which differentiate it from its earlier generation, Web 2.0 are as follows (Cho, 2008; Wheeler 2009a; Berners-Lee, 2001; Morville, 2005; Semweb, 2011):

- Intelligent/semantic Web: The term semantic web refers to the W3C's vision on the Web of linked data enabling people to create data and build vocabularies. .Simply put, semantic web is all about describing things in a form that is understood by computers

- Openness and interoperability: this refers to openness in terms of application programming interfaces, data formats, protocol etc and interoperability between devices and platforms.

- Global repository of data: the ability of information being access across programs and across the web.

- 3D Virtualization: Extensive use of 3D modeling and 3D spaces using services like second life and personalized avatars connected to your devices.

- Control of information: If Web 2.0 is about control of information, then Web 3.0 is about bringing order back to it.

- Socio-Semantic Web which will enable the users to share knowledge.

- Distributed and Cloud Computing: The delivery of computing as a service rather a product

AI and machine learning are the main driving force behind the Web 3.0. For example in web 2.0, searching the word e-Learning on Google will give a plethora of unrelated hits, however the web 3.0 will solve this problem by providing context to searching for online information. As the Web 3.0 is also referred to as the Semantic Web of Data (Berners-Lee Video), there will be huge datasets created, so the need of the time is management of "Big Data," and "Linked data" (Fischetti, 2010). The Web 3.0 will make use of technologies such as RDF (Resource Description Framework, SPARQL (Query Language for RDF), OWL (Ontology Web Language and SKOS (Simple Knowledge Organization System) (W3CSW, 2009); these will help structure information such that programs like web spiders and web-crawlers can search, discover, collect and analyze information from the web (RDF, 2004). "If HTML and the Web made all the online documents look like one huge book, RDF, schema and interface languages will make all the data in the world look like one huge database", (Berners-Lee, 1999).

Figure 1 summarizes the technologies which are popularly used in each generation of the web whereas Figure 2 depicts the divide in the nature of the web in terms of the syntactic web, semantic web and the pragmatic web. Web 1.0 applications are forums, personal Web pages, emails and so on whereas all the social networking application in addition to wikis, blogs, podcast fall under Web 2.0. 
Figure 1: Nova Spivack's Illustration of the Evolution of Web (Nova Spivack, 2007)

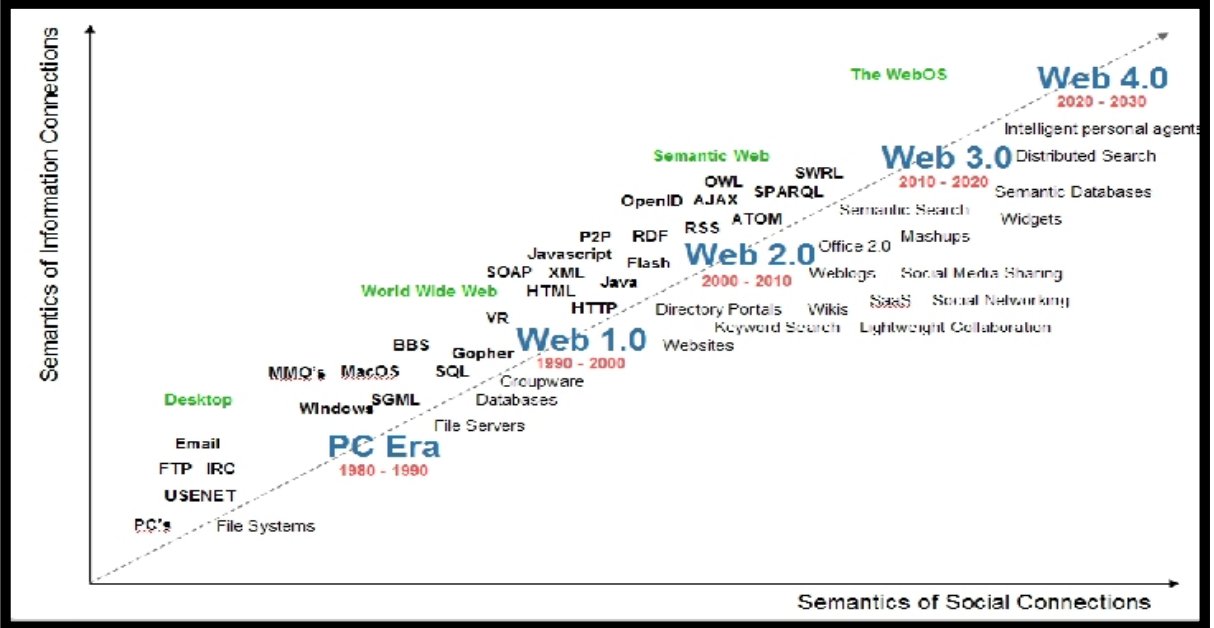

. Figure 2: Illustration of the different nature of the web and its applications (Wheeler, 2011).

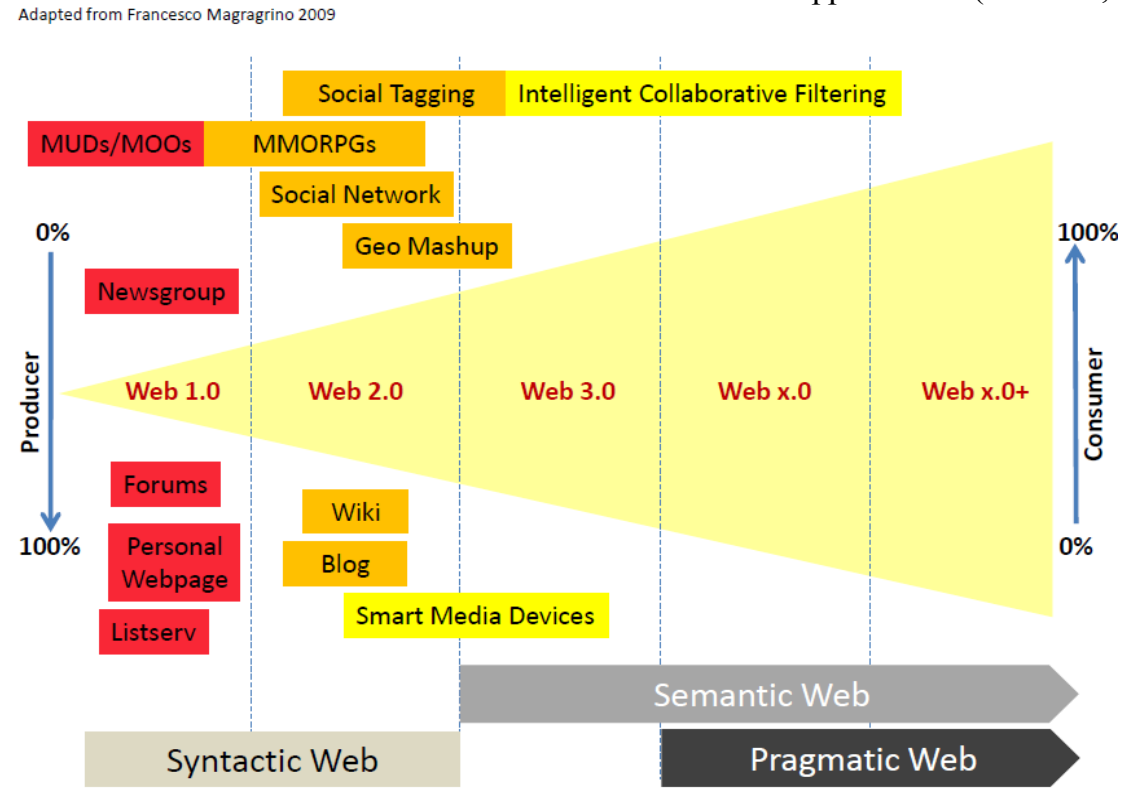

The next sub-section 2.2 presents the evolution of e-Learning describing how the Web technologies have been utilized in development of educational technologies and hence teaching and learning as researchers believe that the "new web technologies enable the application of learning theories to e-Learning" (Ruben et al., 2011 , p. 2).

\subsection{Evolution of e-Learning}

E-learning is usually understood as instruction delivered via a computer in teaching and learning. A number of other terms are synonymously used with e-Learning for example, computer based training, online learning, virtual learning, web-based learning and so on. The central idea is that all these refer to use of information and communication technology that pertain to all educational activities either performed individually or in groups, working online or offline, synchronously or asynchronously, via networked or standalone computers or other electronic devices (Romiszowski, 2004; Garrison and Anderson, 2003).

The Higher Education Funding Council for England (HEFCE) in the 2005 E-Learning Strategy, in their effort to find a suitable definition for e-Learning state (HEFCE, 2005, p.5):

We have debated whether we need to adopt a specific definition of e-learning at all, since it might curb exploration and restrict diversity. However, we believe we should limit the scope of our strategy, to be sufficiently focused, to the use of technologies in learning opportunities.

Elaborating the HEFCE strategy, e-Learning is elaborated by Brenton (2008, p.86) as:

Something that happens when students learn with information and communications technology (ICT).It may happen in distance learning courses or in campus-based courses (this latter is sometimes called 'blended' or 
'mixed-mode' learning). It will usually be defined sufficiently broadly to allow you as a practitioner in your discipline and a teacher of your students to employ a variety of approaches in the way you use it; there is no one way to 'do' e-learning. It is not something you 'deliver'. Rather, it is something you enable your students to do. Each generation of e-Learning is depicted in the Figure 3 and summarized briefly in sub-sections 2.2.1- 2.2.3.

Figure 3: E-Learning evolution in terms of concepts and technologies (Rego, 2011, p. 41)

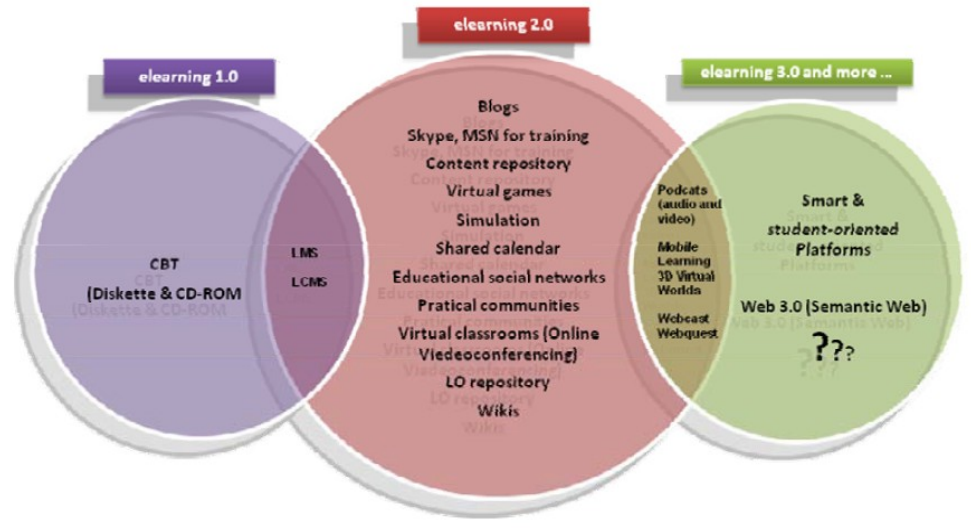

The learner of the future is totally digitalized. The often so-called digital natives, digital immigrants, net-generation, Generation @ are some of the names given by researchers to the students of the time (Prensky, 2001; Tapscott, 1997; Pelevin \& Bromfield, 2002).

\subsubsection{E-Learning 1.0}

With the advent of the Web, making content available online, e-Learning 1.0, quickly adapted to it in terms of creating and administering educational content for viewing online. The concept of "learning objects" came into being which were used to create what is known as the learning (content) management systems (LMS or LCMS) developed to support study management and course organization for learners. This is considered more of the traditional, rather hierarchical way of learning where communication is mono-directional. In this direct-transfer model, the instructor is the distributor of learning material in a media-rich way and may address learners through various communication channels.

\subsubsection{E-Learning 2.0}

Stephen Downes described the use of Web 2.0 technologies for teaching and learning as "e-Learning 2.0" (2005); Even further, Zhang and Adipat (2005) called it u-Learning or ubiquitous learning (inspired by the phrase ubiquitous computing or pervasive computing referring to computing anywhere, anytime, anyhow).

Web 2.0 for example has transformed the class room in terms of how it is not only socially but collaboratively constructed by using wikis, blogs, podcasts, and other social web tools, such tools demand dynamic content generation which may comprise of reflections and conversation, hence requiring collaboration and interaction (Richardson, 2009). It is considered to be a collaborative way of learning where communication is multi-directional; hence, the premise is that knowledge is socially constructed.

\subsubsection{E-Learning 3.0}

Education researchers are now quite freely using the term e-Learning 3.0 in various blogs and discussion forums (Walters, 2010; Moore, 2010, Wheeler, 2009a).

Availability of new technologies, emergence of cloud computing, collaborative intelligent filtering, increased and reliable data storage capacity, higher screen resolutions, multi gesture devices and 3D touch user interface leads us into the next generation of e-Learning. One of the big things of third generation of e-Learning will be the ubiquitous access to learning resources with the use of mobile devices to virtually access anything, anytime and anywhere (Baird 2007; Wheeler 2009a). Technology people also suggest the use of AI and data mining for building the e-Learning 3.0 systems which have the capability to sift and sort big data, provide linked data to assist learner and also gain a deeper and better understanding of the learning process itself (Rubens et al., 2011). Further education researchers believe that the underlying concept of "anytime, anywhere and anybody" will be supported by "anyhow". This functionality of "anyhow" will be provided by virtual 3D worlds such as use of Second Life and personal avatars (Baird 2007; Rego 2010). With well-established Web 2.0 technologies and moving ahead to Web 3.0, research communities are talking about the personal learning environments (PLEs also referred to as mash-ups). "Personalization is seen as the key approach to handle the plethora of information in today's knowledge-based society." (Ebner et al., 2011, p. 22). 
Another transformation of the e-Learning will occur in scientific research process; moving away from traditional top down, hypothesis driven approach to bottom-up, data-driven approach. So much data is available that data-sets will lead researchers and learners to devise hypothesis (Nelson, 2009).

E-Learning 3.0 systems are not prevalent commercially yet; however researchers are proposing such solutions as proof-of-concepts or working prototypes. One of the first online services to use semantic web automatically and intelligently organizing information about users' specific interests is Twine (Spivack's, 2010). Another example of a true e-learning 3.0 system is AHKME (Adaptive Hypermedia Knowledge Management E-Learning Platform) an e-Learning Information System having web-based learning requirements compliant with a Web 3.0 philosophy (Rego, 2011).

\subsection{Relationship between Web evolution and e-Learning evolution}

Relating the generations of the Web with generations of e-Learning, if web 1.0 was the read web and web 2.0 is the read/write web then the web 3.0 is the read/write/truly collaborate web. Furthermore, e-Learning 1.0 was about providing access to the information to the learners, e-Learning 2.0 in addition to all e-Learning 1.0 capabilities provided authoring and interacting capabilities to the learner. On those lines, e-Learning 3.0, enabled and enriched with web 3.0 technologies may promote intelligently collaborative, rich 3D virtual learning environments which will bring learners together for anytime, anywhere, anyhow learning experience utilizing the semantic capabilities to parse the global databases of knowledge. Since, "both previous generations of e-Learning (1.0 and 2.0) closely parody the prevalent technologies available in their kin Web versions (1.0 and 2.0, respectively) (Rubens et al., 2011)," it can be deduced that e-Learning 3.0 will provide all earlier generations capabilities enhanced with the web 3.0 technologies. The early Web 2.0 technologies and the Web 3.0 are transformative and disruptive technologies which may further transform learning and teaching (with relation to e-learning). From being a receiver of information form passive web, the learner had become a creator and author in the active, intelligent, virtual and social learning platform. The relationship between the generations of the Web and e-Learning are summarized in Table 1.

Ebner (2007) while attempting to answer whether e-Learning 2.0 is just a sum of the e-Learning 1.0 and Web 2.0 technologies, posited that the human factor is also important; that is, not only the readiness for also but acceptability of humans towards a new technology. Therefore, Ebner (ibid) revised his equation to be eLearning $2.0=\mathrm{f}$ (e-Learning 1.0, Web 2.0, human factor). In the context of this paper, when accepting Web 3.0 technologies for e-Learning 3.0, the human factor will also play some role but maybe not a significant one because the transition for the aforementioned "digital natives" will be much quicker, as for them internet is a way of life.

Table 1: Relationship between generations of Web and e-Learning (adapted from Rego, 2011).

\begin{tabular}{|c|c|c|c|c|}
\hline \multicolumn{5}{|c|}{ Relationship between the Web and E-Learning generations } \\
\hline & \multicolumn{2}{|c|}{ Web } & \multicolumn{2}{|c|}{ E-Learning } \\
\hline Version & Concept & Technologies & Concept & Technologies \\
\hline 1 & $\begin{array}{l}\text { Read-only or write } \\
\text { only, } \\
\text { Accessibility, security, } \\
\text { web of documents }\end{array}$ & HTML, HTTP,URL & $\begin{array}{l}\text { Content management, } \\
\text { Unidirectional activities }\end{array}$ & $\begin{array}{l}\text { CBT, LMS, eBooks } \\
\text { VLEs, }\end{array}$ \\
\hline 2 & $\begin{array}{l}\text { Read/write } \\
\text { Social web }\end{array}$ & $\begin{array}{l}\text { Dynamic } \\
\text { technologies, DHTMS. } \\
\text { ASP, AJAX, widgest, } \\
\text { podcasts, SNS }\end{array}$ & $\begin{array}{l}\text { Blended learning, } \\
\text { content } \\
\text { sharing, } \\
\text { Bidirectional activities, } \\
\text { Multimedia content }\end{array}$ & $\begin{array}{l}\text { LCMS, social networks, } \\
\text { video conf } \\
\text { VLEs with social } \\
\text { capability, Mashups }\end{array}$ \\
\hline 3 & $\begin{array}{l}\text { Read/write/request/colla } \\
\text { borate } \\
\text { Semantic web, big data, } \\
\text { linked data, global } \\
\text { database }\end{array}$ & $\begin{array}{l}\text { RDF, XML, OWL, 3D, } \\
\text { second life }\end{array}$ & $\begin{array}{l}\text { Learner-centered, } \\
\text { U-learning, knowledge } \\
\text { representation }\end{array}$ & $\begin{array}{l}\text { PLEs, Mashups } \\
\text { Social semantic web, } \\
\text { second life, personal } \\
\text { avatars }\end{array}$ \\
\hline
\end{tabular}

III. Do we need a Learning theory for the Web 3.0?

The digital native generation having access to high bandwidth internet access, on mobile devices and smart phones, cannot imagine living in a world without digital technologies. Information on the fly and on the go has become a norm for them (Oblinger \& Oblinger, 2005; Oblinger, 2005). Consequently, the question is, does all the advancement on technology signal a change in the learning behavior, so, for that matter, do we need a learning theory for the digital natives? Based on review of the literature of approaches to learning theories, the paper makes a preliminary attempt to address this concern.

Recently, education researchers are discussing the need of a new learning theory for the semanticsocial web and whether connectionism is adequate in terms of its coverage of the need for the digital age. 
George Siemens' Connectivist approach to learning in a digital age might actually be superseded by our need to reconceptualize the whole idea of what learning will mean - especially when we are immersed in a world of ambient mobile pervasive communication where intelligent agents and filtering tools do our bidding for us. Connectionism is so Web 2.0 (Miechel, 2009; Wheeler, 2009b).

Learning theory refers to a framework that helps us to think about how and why change (in learning) occurs (Smith, 1999). A review of the literature shows that there are different orientations and approaches to explaining how this process of learning takes place, for example, the behaviourist, the cognitivist, humanistic, the social/situational and the connectivist approaches to learning. Broadly speaking, in the education literature, there is reference to four theories of learning namely Behaviorism, Cognitivism, Constructivism and Connectivism. In Behaviorism knowledge is perceived as facts that can be transferred from teacher to student (can be related to e-Learning 1.0) Cognitivism opens up the black box of the mind, considering the learner as an information processor whereas Constructivism suggests that learners create knowledge as they try to make meaning of their experiences. Connectivism, considered to be the learning theory of the digital age, according to Siemens (2004) is, "a successor to behaviorism, cognitivism, and constructivism." These theories of learning are briefly described in Table 2, in terms of the view of the learning process, locus of learning and purpose of education; Table 2 is adapted from Ashworth et al., (2004) adding a column to relate with the connectivist approach (Siemens, 2004).

Table 2: Summary of learning theories (adapted from Ashworth et al., 2004; Seimens, 2004).

\begin{tabular}{|c|c|c|c|c|}
\hline \multicolumn{5}{|c|}{ Theories of Learning } \\
\hline Aspect & Behaviorist & Cognitivist & Constructivist & Connectivist \\
\hline $\begin{array}{l}\text { Learning } \\
\text { theorists }\end{array}$ & Skinner, Pavlov, & $\begin{array}{l}\text { Bruner, Kohler, } \\
\text { Piaget }\end{array}$ & Bandura, Vgotsky & Seimerns, Downes \\
\hline $\begin{array}{l}\text { View of the } \\
\text { learning } \\
\text { process }\end{array}$ & Change in behavior & $\begin{array}{l}\text { Internal mental } \\
\text { processes }\end{array}$ & $\begin{array}{l}\text { Construction of } \\
\text { meaning from } \\
\text { experience }\end{array}$ & $\begin{array}{l}\text { Connecting } \\
\text { specialized } \\
\text { information sets }\end{array}$ \\
\hline $\begin{array}{l}\text { Locus of } \\
\text { learning }\end{array}$ & $\begin{array}{l}\text { Stimuli in external } \\
\text { environment }\end{array}$ & $\begin{array}{l}\text { Internal cognitive } \\
\text { structuring }\end{array}$ & $\begin{array}{l}\text { Internal construction } \\
\text { of reality by } \\
\text { individual }\end{array}$ & $\begin{array}{l}\text { Draw information } \\
\text { outside of our } \\
\text { primary knowledge }\end{array}$ \\
\hline $\begin{array}{l}\text { Purpose of } \\
\text { education }\end{array}$ & $\begin{array}{l}\text { Produce behavioral change in } \\
\text { desired direction }\end{array}$ & $\begin{array}{l}\text { Develop capacity and } \\
\text { skills to learn better }\end{array}$ & Construct knowledge & $\begin{array}{l}\text { Ability to synthesize } \\
\text { and recognize } \\
\text { connections }\end{array}$ \\
\hline
\end{tabular}

Connectivism applies ideas from biological models of the brain to neural networks in machine learning; stating its basic principles as follows (Seimens, 2004):

- Learning and knowledge rests in diversity of opinions.

- Learning is a process of connecting specialized nodes or information sources.

- Learning may reside in non-human appliances.

- Capacity to know more is more critical than what is currently known

- Nurturing and maintaining connections is needed to facilitate continual learning.

- Ability to see connections between fields, ideas, and concepts is a core skill.

- Currency (accurate, up-to-date knowledge) is the intent of all connectivist learning activities.

This paper does not indulge in the debate of whether connectionism is a theory or a phenomenon or for that matter does not attempt to counter some of the criticisms done about it. The simple approach taken in this paper is to examine the important principles of the connectivist theory of learning as stated by Seimens (2004) and then look at the significantly new technologies which will be introduced as a result of the advancements in the web technologies, thus compare and relate which technological shift may be supported by the principles of the connectionist learning theory; this is demonstrated in Table 3. It appears that technologies of the Web 3.0 can be supported by the so called, learning theory of the digital age, based on its basic principles.

Table 3: Web 3.0 technologies supported by basic principles of connectivism.

\begin{tabular}{|c|c|}
\hline Web 3.0 technologies used in e-Learning 3.0 & Basic principles of connectivism \\
\hline Social semantic networks, openness and interoperability & Learning and knowledge rests in diversity of opinions. \\
\hline $\begin{array}{l}\text { Big data or global data repository, linked data, cloud } \\
\text { computing, extended smart mobile technology }\end{array}$ & $\begin{array}{l}\text { Learning is a process of connecting specialized nodes or information } \\
\text { sources. Currency of knowledge is important. }\end{array}$ \\
\hline $\begin{array}{l}\text { Machine learning, artificial intelligence, personal avatars, 3D } \\
\text { visualization and interaction }\end{array}$ & Learning may reside in non-human appliances. \\
\hline Semantic web, control of information & Capacity to know more is more critical than what is currently known \\
\hline Semantic web, collaborative intelligent filtering & $\begin{array}{l}\text { Ability to see connections between fields, ideas, and concepts is a } \\
\text { core skill. }\end{array}$ \\
\hline Semantic web, collaborative intelligent filtering & $\begin{array}{l}\text { Nurturing and maintaining connections is needed to facilitate } \\
\text { continual learning }\end{array}$ \\
\hline
\end{tabular}


Based on the relationship illustrated in Table 3, the paper posits that the cutting edge technologies to be a part of e-Learning 3.0 are adequately supported by the principles of the learning theory of connectivism. Hence a call for a new learning theory for e-Learning 3.0 is probably not justified.

\section{Challenges and Issues related to e-Learning 3.0}

A review of the secondary literature shows various challenges and issues may arise due to prevalence and adoption of e-Learning 3.0 technologies, some of which are:

- Increased privacy and security risks,

- Web accessibility

- Readiness of the users, be it the learner or the tutor

- Requirement for further standardization of e-Learning technologies

- Social issues in term of increase of the digital divide

\subsection{Increased privacy and security risks}

In the MashUps of the interconnected world in the hyperspace, there is an increased risk of privacy of data due to difference in privacy laws from country to country. Also, added security risks may be faced due to invalid input, a lack of server-side checks, and excessive privileges (Weippl, and Ebner, 2008). Researchers are concerned that the ethical dilemmas will also be enhanced as due to the nature of the semantic web, vastness, vagueness, uncertainty and inconsistency may add to privacy and loss of control (Alves, et al., 2011; Alkhateeb et al., 2010).

\subsection{Web Accessibility issues}

Similar to other web-based applications, there is going to be more of a challenge to provide accessibility with web content to people with special needs. There have been some initiatives from the world wide web consortium on this (WAI, 2009) but much more work will be required in this direction.

\subsection{Readiness of the users}

There are researchers who are apprehensive about the use of such advanced technology. "There are teachers who are still struggling with web 1.0 let aside the students. So the questions or apprehensions on the other side are: are our students truly ready to be autonomous learners? Are our teachers willing to give into technology? (Wheeler, 2009a)" As suggested earlier in section 2.3, the human factor is definitely a variable in the equation, the impact should reduce as the users become more and more comfortable with technology.

\subsection{Standardization of e-Learning technologies}

This is in relation to exchange of data and content between systems. Some standard do exist will have to be enhance for the future generation of the web for example, sharable course object reference model (SCORM), IEEE learning technology standards committee (LTSC), Instructional Management Systems project (IMS) and so on. Educational technology standardization movement has become an important force, for example IMS Global Learning Consortium (IMS, 2011), IEEE (IEEELOM, 202), Dublin Core (DC, 2010) which are basically working towards standardization of educational technologies for e-Learning applications such as metadata, digital repositories, and many more.

\subsection{Social issues}

Researchers also argue that another issue would be to not only further increase the digital divide but also change the nature of it. "Digital divides of the future will not focus on 'have and have not' socio-economic divides, but will more likely be 'will and will not' psychological divides, and 'can and cannot' skills divides. (Wheeler, 2009a)". Hence, all the challenges and issues related to earlier generations will become more prominent and will call for increased attention.

\section{Conclusion}

This paper explores how Web 3.0 technologies will entail e-Learning 3.0; whether the need for a new learning theory is called for with the use of the Web 3.0 in educational technologies and what are the potential challenges and issues related to the advent of e-Learning 3.0. The evolution of e-Learning (e-Learning 1.0, eLearning 2.0 and e-Learning 3.0) is related to the three generations of the Web (Web 1.0, Web 2.0 and Web 3.0). Web 2.0 and the associated technologies are well established and accepted by the user and the prevalence of these in e-Learning is common. Just like its predecessor, this paper posits that Web 3.0 technologies, once stable and well developed will further transform the e-Learning discipline. However, it does not seem that there is a need to call for a new learning theory as the theory of connectivism should encompass the changes. However, with the advent of any technology and its adoption, use of Web 3.0 and e-Learning will come with a 
plethora of technological, social, legal and ethical issues. In other words, the equation in the title can be modified to E-learning 3.0 = $f$ (E-learning 2.0, Web 2.0, other factors and challenges), (here $f$ means a function $o f$ ). Advanced technologies will continue to play a central role in the development and evolution of e-Learning, however it will do so more in the background providing connections between knowledge; so technology is not merely an enabling tool in education, rather a driver of change. So, keeping pace with the unprecedented innovations in technology, the education domain has also evolved. Use of technology in education has had a significant impact on teaching and learning. E-Learning systems have also evolved with the evolution of the Web and the new technologies will continuously enable the application of learning and teaching theories into eLearning practice.

\section{Acknowledgement:}

This is to declare that part of this paper was presented at the Cognition and Exploratory Learning in Digital Age 2012 (CELDA 2012) conference and included in the proceedings of the same.

\section{References}

[1]. Alkhateeb,F., AlMaghayreh, E., Aljawarneh, S., Muhsin, Z and A. Nsour. E-learning Tools and Technologies in Education: A Perspective. E-learning, 2010.

[2]. Alves da Silva, N., Morais da Costa, G., Prior, M. and Rogerson, (2011). The Evolution of E-learning Management Systems: An Ethical Approach. International Journal of Cyber Ethics in Education (IJCEE), 1(3):12-24.

[3]. Ashworth, F., Brennan, G., Egan, K., Hamilton, R. and Saenz, O (2004). Learning Theories and Higher Education. Level3, Issue 2. Retrieved from http://arrow.dit.ie/cgi/ on March 01, 2012.

[4]. Baird, D. (2007). Learning 3.0: Mobile, Mobile, Mobile Barking Robot. Retrieved March 21 , 2012 from http://www.debaird.net/blendededunet/2007/02/learning 30 mob.html

[5]. Berners-Lee, T. (1995). Past, Present and Future, IEEE Computer, 29 (10), 69-77.

[6]. Berners-Lee. T, Hendler, J., and Lassila, O. (2001). The Semantic Web, Scientific American, 284(5), 34-43.

[7]. Berners-Lee Video. Berners-Lee, T. (2008). The Semantic Web of Data. Retrieved from http://www.youtube.com/watch?v=HeUrEh-nqtU on March 27, 2012

[8]. Brenton, S. (2008) e-Learning: An Introduction. Chapter in Fry, H. Ketteridge, S. and Marshal, S. (eds.) (2008) A Handbook for Teaching and Learning in Higher Education. 3rd Ed. London, Kogan Page.

[9]. Cho, A. (2008). What is Web 3.0? Suite101. Retrieved from http://www.suite101.com/internet on March $20,2012$.

[10]. DC. (2010). Dublin Core Metadat Initiative . Retrieved from http://dublincore.org on March 26, 2012.

[11]. DiNucci, D. (1999). Fragmented Future. Print 53 (4): 32. Retrieved from http://darcyd.com/fragmented future.pdf on March 26, 2012.

[12]. Downes, S. (2005). E-Learning 2.0. ACM, eLearn Magazine, October 2005(10).

[13]. Ebner, M. (2007). E-learning $2.0=$ e-learning $1.0+$ web 2.0? In The Second International Conference on Availability, Reliability and Security, 2007. ARES 2007, held in Vienna, Austria. pp 1235 - 1239.

[14]. Ebner, M., Schön, S., Taraghi, B., Drachsler, H., \& Tsang, P. (2011). First steps towards an integration of a Personal Learning Environment at university level. In R. Kwan et al. (Eds.), ICT 2011, CCIS 177 (pp. 22-36), Springer-Verlag Berlin: Heidelberg.

[15]. Fischetti, M. (2010). The web turns 20. Linked data gives people power. Scientific American. Retrieved from http://www.scientificamerican.com/article.cfm?id=berners-lee-linked-data on March 22, 2012.

[16]. Forrester Research, (2006).Search engine usage report, available at http://www.forrester.com/home. Retrieved from http://www.seowritingjobs.com/organic-search-engine-results-why-they-mean-more-work-for-seo-copywriters/ on March $21,2012$.

[17]. Garrison, D. R. and Anderson, T. (2003). E-Learning in the 21st century: A framework for research and practice. London: Routledge/Falmer.

[18]. HEFCE (2005) HEFCE Strategy for E-Learning 2005/12. Bristol, UK, Higher Education Funding Council for England (HEFCE), Retrieved from http://www.hefce.ac.uk/pubs/hefce/2005/05_12/ on March 10, 2012

[19]. IMS. (2011). IMS Specification. IMS Global Learning Consortium, Retrieved from http://www.imsglobal.org/cc/index.html in March 2012.

[20]. Meichel Blog. Meichel, F., (2009). Qu'est-ce que la cognition - points de repères en sciences cognitives Qu'est-ce que la cognition - points de repères en sciences cognitive. Retrieved March 20, 21012 from http://florencemeichel.blogspot.com/2009/05/quest-ce-que-la-cogntion-points-de.html. (English translation found at Wheeler, 2009b)

[21]. Moore, D. (2010) Web 2.0. Darcy Moore's Blog. Retrieved March 21, 2012 from http://darcymoore.net/

[22]. Morville, P. (2005). Ambient Findability: O'Reilly Media.

[23]. Nelson, M. L. (2009). Data-Driven Science: A New Paradigm? EDUCAUSE Review, 44(4):6-7.

[24]. O'Reilly, T. (2004). What is Web 2.0: Design patterns and business models for the next generation of software. Retrieved from http://www.oreillynet.com/pub/a/oreilly/tim/news/2005/09/30/what-is-web-20.html in March 2012.

[25]. Oblinger, D. D., \& Oblinger, J. L. (2005). Educating the Net Generation. Educause. Retrieved from http://www.educause.edu/educatingthenetgen in March 2012.

[26]. Oblinger, J. L. (2005). Is it age for IT: First steps Towards Understanding the Net Generation. Educating the Net Generation, 2.11.5. Retrieved from http://www.educause.edu/ir/library/pdf/pub7101b.pdf in March 2012.

[27]. Prensky, M. (2001). Digital natives, Digital Immigrants, On the Horizon, 9(5), p. 1-6.

[28]. RDF, (2004). Resource Framework Description W3c Semantic Web. Retrieved from http://www.w3.org/RDF in March 2012.

[29]. Rego, H. Moreira, T., Morales, E. and Garcia. F. J. (2010). Metadata and Knowledge Management drivenWeb-based Learning Information System towardsWeb/e-Learning 3.0. International Journal of Emerging Technologies in Learning (iJET), 5(2):36-44.

[30]. Rego, H. (2011) AHKME eLearning Information System: A 3.0 Approach. Unpublished PhD thesis at University of Salamanca.

[31]. Richardson, W. (2009) "Blogs, Wikis, Podcasts and other Powerful Web Tools for the Classrooms" Cornwin Press California USA.

[32]. Romiszowski, A. (2004). How's the e-learning baby? Factors leading to success or failure of an educational technology innovation, Educational Technology, 44(1). 
[33]. Rubens, N., Kaplan, D., and Okamoto, T. (2011). E-Learning 3.0: anyone, anywhere, anytime, and AI. In International Workshop on Social and Personal Computing for Web- Supported Learning Communities (SPeL 2011).

[34]. Semweb. (2011). Semantic Web Tutorial. W3Schools, Retrieved from http://www.w3schools.com/semweb/default.asp in March 2012.

[35]. Siemens, G. (2004). Connectivism: A learning theory for the digital age. Retrieved from http://www.elearnspace.org/Articles/connectivism.htm. on March 26. 2012.

[36]. Smith, M. K. (1999). Learning theory. The encyclopedia of informal education. Retrieved from www.infed.org/biblio/b-learn.htm in March 2012.

[37]. Spivack, N. (2007). Nova Spivak Blog. Retrieved from http://novaspivack.typepad.com/nova spivacks weblog/radar networks/ in March 2012.

[38]. Spivack, N. (2010). Twine. Retrieved from http://www.novaspivack.com/?s=Twine On March 22, 2012.

[39]. Tapscott, D. (1997).Growing up digital: The Rise of the Net Generation. New York: McGrwa-Hill.

[40]. W3CSW. (2009). Semantic Web Activity W3C. Retrieved March 22, 2012 from http://www.w3.org/2001/sw/

[41]. WAI, (2009). Web Accessibility initiatives. Retrieved March 22, 2012 from http://www.w3.org/WAI/.

[42]. Waters, S. (2010). Sue Waters Blog, Retrieved March 21, 2012 from http://suewaters.com/

[43]. Weippl, E. and Ebner, M. (2008). Security Privacy Challenges in E-Learning 2.0. In C. Bonk et al. (Eds.), Proceedings of World Conference on E-Learning in Corporate, Government, Healthcare, and Higher Education 2008 (pp. 4001-4007). Chesapeake, VA: AACE.

[44]. Wheeler Blog. Wheeler, S. (2009b). Learning with e's. Retrieved March $20,2012 \quad$ from http://stevewheeler.blogspot.com/2009/05/connectivism-dead.html\#!/2009/05/connectivism-dead.html

[45]. Wheeler, S. (2009a). E-Learning 3.0, Learning with e's. Retrieved March 21, 2012 from http://stevewheeler.blogspot.com/2009/04/learning-30.html\#!/2009/04/learning-30.html

[46]. Wheeler, S. (2011). E-Learning 3.0: Learning through the eXtended. Smart Web. Steve Wheeler. University of Plymouth. Keynote Speech for National IT Training Confernece, Dublin, Ireland. Retrieved March 12 , 2012 from http://ittrainingconference.files.wordpress.com/2011/04/ittc stevewheeler smartweb.pdf

[47]. Zhang, D. S., \& Adipat, B.(2005). Challenges, methodologies, and issues in the usability testing of mobile applications. International Journal of Human-Computer Interaction, 18(3), 293-308. 